\title{
WATER FOR LIFE: NATURAL RESOURCE AND ESSENTIAL HUMAN RIGHTS TO SUSTAINABLE
} DEVELOPMENT ${ }^{1}$

Clara Machado²

Rayza Ribeiro Oliveira ${ }^{3}$

\begin{abstract}
The alarming and increasing scarcity of drinking water on the planet adds a new paradigm in the international legal scene, in order to protect human life and ensure the promotion of quality of life for present and future generations as a form of sustainable development, that is, the paradigm of the human right to water. Thus, this article aims to present, through the evolution of the environmental theme in the international scenario, in view of the consideration of water as an objective of sustainable development in the UN 2030 Agenda, the new conception of the right to water, from the recognition of the right to the healthy environment, both being human rights, essential to the quality of life and the dignity of human life. Finally, to conclude that, although the right to water is not yet recognized as a human right in the Brazilian legal system, there is a growing mobilization in this regard in the national scenario. The methodology used was based on a qualitative approach to the problem, being a research of exploratory nature, using the methodological procedure of bibliographical and documentary research, through the analysis of doctrines, documents, legislation and other scientific texts related to the subject.
\end{abstract}

Keywords: 2030 Agenda. Sustainable development. Right to water. Environment.

Resumo: A alarmante e crescente escassez de água potável no planeta aduz um novo paradigma no cenário jurídico internacional, a fim de proteger a vida humana e garantir a promoção de qualidade de

\footnotetext{
${ }^{1}$ This research was supported by CAPES/PROSUP and it is the result of studies carried out from the subject "Sustainable Human Development", of the master's degree programme in human rights at Tiradentes University, as well as results of the activities of the Human Rights, Environment and Sustainability Study Group (GEDHAS).

${ }^{2}$ Doutora em Direito pela Universidade Federal da Bahia. Mestre em Direito pela Universidade Federal da Bahia. Pós graduada em direito público pela Uniderp. Graduada em Direito pela Universidade Federal de Sergipe. Professora d curso de Mestrado em Direitos Humanos da UNIT e de cursos de Graduação e pós graduação da UNIT, Estácio-Fase, Ciclo Renovando Conhecimentos e EJUSE. Advogada militante em Direito Público. Universidade Tiradentes. Brasil. E-mail: claracardosomachado@gmail.com

${ }^{3}$ Mestranda em Direitos Humanos pela Universidade Tiradentes (UNIT). Bolsista CAPES. Pós-graduanda em Direito Urbanístico e Ambiental pela Pontifícia Universidade Católica de Minas Gerais (PUC/MG). Graduada em Direito pela Universidade Tiradentes (UNIT). Coordenadora-discente do Grupo de Estudos em Direitos Humanos, Ambiente e Sustentabilidade (GEDHAS) e integrante dos Grupos de Pesquisa: Direitos Fundamentais, Novos Direitos e Evolução Social e DhFiloS: Direitos Humanos, Filosofia e Sustentabilidade - UNIT, ambos com registro no CNPq. Universidade Tiradentes. Brasil. E-mail: yzaribeiroc@gmail.com
} 
vida para as gerações atuais e futuras como forma de desenvolvimento sustentável, qual seja, o paradigma do direito humano à água. Assim, o presente artigo tem por objetivo apresentar, através da evolução da temática ambiental no cenário internacional, diante da consideração da água como objetivo de desenvolvimento sustentável na Agenda 2030 da ONU, a nova concepção do direito à água, a partir do reconhecimento do direito ao meio ambiente sadio, sendo ambos direitos humanos, essenciais à qualidade de vida e à dignidade de vida humana. Para ao final, concluir que, embora o direito à água ainda não seja reconhecido como direito humano no ordenamento jurídico brasileiro, há uma crescente mobilização nesse sentido no cenário nacional. A metodologia utilizada deu-se através de uma abordagem qualitativa do problema, sendo a pesquisa de natureza exploratória, utilizando-se do procedimento metodológico da pesquisa bibliográfica e documental, através da análise de doutrinas, documentos, legislações e demais textos científicos relacionados ao tema.

Palavras-chave: Agenda 2030. Desenvolvimento sustentável. Direito à água. Meio ambiente.

\section{INTRODUCTION}

In September 2015, during the United Nations General Assembly in New York, representatives of 193 Member States agreed that poverty eradication was the main goal to be full sustainable development. They have adopted the document "Transforming Our World: The 2030 Agenda for Sustainable Development" (A/70/L.1), which contains 17 objectives and 169 goals for poverty eradication and the promotion of a decent life to all.

Therefore, over 15 years, the objectives and goals set in the above-mentioned document by the Member States should be observed. Among the 17 objectives, the sixth one is the availability of drinking water to all as a goal to achieve sustainable development and, thus, the effective dignity of life for men. It is about this objective that the present work intends to delineate.

This article aims to present the identification of the human right to water, starting from the understanding of the human right to the healthy environment, considering the recognition of access to drinking water as an objective of sustainable development in the UN 2030 Agenda.

In the first instance, it will be demonstrated that treating water as an essential right to the maintenance of life is essential for the promotion of human dignity is a recent discussion. In the global scenario, in the mid-1970s, attention was drawn to the water issue by the States, especially in relation to the meetings of the members of the United Nations (UN), reverberated only the idea of attention to 
the finitude of water resources and the concern with such interference in the economy, given the valorization of the right to development.

The intention of international bodies to discuss the exhaustion of natural resources, and especially with regard to water, denotes the paradigm shift that occurred during the 20th century and will be explained in the second part of this article, when environmental causes began to occupy important spaces in the face of discussions at the world summits, which until then were marked by negotiations on essentially economic and social matters, without real consideration of environmental issues.

However, in spite of the progress of the discussions on the environment in the world scenario, there was no understanding at the time of the indispensability of the recognition of water as a human right, necessary for the perpetuation of life. However, this position has been altered and this new panorama, which reveals a growing acceptance of water as a human right, is inserted in the context of the recognition of the human right to the healthy environment or even belonging to a new dimension of fundamental rights, it will be approached in the final part of this work.

For the purposes intended in this paper, a qualitative approach will be performed, being a research of exploratory nature, using the methodological procedure of the bibliographical research, through the analysis of doctrines, legislation and other scientific texts related to the theme to present some discussions on the theme of water which permeated the debates between the UN member states during the 1970s and 1990s, providing a change of vision on the subject, culminating in the current panorama of recognition of water as a human right, fundamental to life and human dignity, just as the right to a healthy environment is now understood, identifying water as a necessary objective for the sustainable development of the planet.

\section{ENVIRONMENT AND WATER ON THE INTERNATIONAL POST-WAR AGENDA}

After the two great world wars, in 1914 and 1939, the world scenario was one of horror and devastation in the face of the consequences of these two war periods the mankind went through. Destroyed cities, decimated populations, homeless people, to name just a few of the endless sequels of this phase.

From this situation, States, noting the need to unite and strengthen the bloc against the powers of the axis even after the end of World War II, at a meeting held in San Francisco in the United States from April 25 to June 26, 1945, drafted the Charter of the United Nations, which later became the 
founding document of the United Nations, the UN (ONU, 2018).

Thus, the creation of the UN demarcates the emergence of a new international order that presents itself to the world with the purpose of modifying the existing international relations. Concerns about international security, peacekeeping, international cooperation mechanisms, as well as protection of the environment were discussed on a global scale (PIOVESAN, 2011).

States, therefore, through their representatives, have come to meet in conferences to promote debates on common social, economic and environmental issues in all parts of the planet, as well as to find solutions to address such problems.

Faced with the need to make decisions regarding environmental issues due to the recognition of the conditions of natural resource debility after the war period, the UN member states convened in 1972 the United Nations Conference on the Human Environment in Stockholm, Sweden.

This conference became a milestone in the history of the evolution of environmental consideration on the international agenda. According to Ana Paula Liberato (2010), it was at this conference that the international community began to observe the level of environmental degradation occasioned by the economic development project intended by the countries.

The final document, the "Declaration of the Environment", proclaims in its first principle the fundamental right of man "To the enjoyment of adequate living conditions in an environment of such quality as to enable them to lead a dignified life and enjoy well-being, with a solemn obligation to protect and improve the environment for present and future generations"(BRASIL, 1972).

It is observed, therefore, the consideration of the healthy and balanced environment as a fundamental right of the human person, taking into account their protection in order to secure the quality of life, from the preservation of nature and the maintenance of the ecological balance (SILVA, 2010). It should be noted that "the direct concern was not with the environment itself, but with the development of the countries that were part of that Conference" (LIBERATO, 2010, p. 21).

With regard to water, it is worth mentioning that the second principle is the preservation of natural resources such as air, water, soil, flora and fauna from a "careful thought or planning" in order to be protected for the benefit of the next generations (BRASIL, 1972).

In this way, attention to water was related to the factor of the finitude of its resources for the maintenance of present and future human life and not properly to a value as a fundamental right as such.

In 1977, the first specific international conference on water took place in Argentina, the United 
Nations Conference on Water. The conference decided on the plan of action to be undertaken by the states to provide drinking water, as well as guidelines on water use in agriculture and mechanisms for promoting basic sanitation for the populations. The final conference document also proclaimed:

All peoples, whatever their stage of development and their social and economic conditions, have the right to have access to drinking water in quantities and of a quality equal to their basic needs [...] It is universally recognized, that the availability to man of that resource is essential both for life and his full development, both as an individual and as an integral part of society (INTERNATIONAL ENVIRONMENTAL LAW RESEARCH CENTER, 1977).

In view of this, it is inferred the beginning of the change of heart of the powerful countries over water, consecrating its access of quality and in sufficient quantity to the satiety of human needs as a right of all peoples.

Another important water-related milestone on the international scene came from the UN designation of the International Drinking Water Supply and Sanitation Decade from 1981 to 1990, in which the Member States have resolved "accelerate substantially the pace of their programmes for drinking-water supply and sanitation through the adoption of relevant policies and their implementation through plans aimed at covering the total population" (WORLD HEALTH ORGANIZATION, 1981).

Also in the 1990s, an International Conference on Water and Environment was held in Dublin, Ireland, to discuss new approaches, development, and management of freshwater resources. According to the conference resolution, the implementation of these new approaches would require political commitment and the involvement of the highest levels of government with the smaller communities.

A commitment will need to be backed by substantial and immediate investments, public awareness campaigns, legislative and institutional changes, technology development, and capacity building programmes. Underlying all these must be greater recognition of the interdependence of all peoples, and of their place in the natural world (UN, 1992).

The idea of internal cooperation between the State and communities for the maintenance of water quality and for water security of the populations is present in this text, thus affirming the importance of water in public policies with a view to enhancing the dignity of the human person.

In Rio de Janeiro, in 1992, the United Nations Conference on Environment and Development also brought important advances in the disclosure of water as a natural resource necessary for all aspects of life. At this conference, attention was drawn to the problems of water scarcity from climate change, air pollution, and poor water management. 
The final report of the conference, Agenda 21, contains 18 chapters on guidelines for the protection of the quality and supply of water resources, and ensures as a general objective the maintenance of an adequate supply of good quality water for the entire population of the planet, together with the preservation of the hydrological, biological and chemical functions of ecosystems, adapting human activities to the limits of nature's capacity and combating vectors of water-related diseases (ONU, 1995).

Given the importance of water, with regard to human health, development and social wellbeing, observed in the international discussions of the twentieth century presented above, at the turn of the millennium (2000), the 8 Millennium Development Goals (MDGs) were presented which contain a direct link to the efficient supply and quality of water supply in many of their objectives (ONU, 2018).

Although there is no explicit mention of water among the MDGs, the importance of maintaining and preserving this natural resource is embedded in the role of objective 7 , for example, on quality of life and respect for the environment through sustainable development, contributing to the reduction of the loss of biological diversity and the proportion of the population without access to drinking water and sewage, encompassing the index of proportion of water resources used to measure this objective in concrete terms.

Already in the 21st century, the UN, with the aim of promoting public sensibilization and awareness about water resources, declared the year 2003 the International Year of Drinking Water and proclaimed the decade 2005-2015 as the International Decade of Action "Water for Life".

The UN Millennium Development Goals Report, released in 2015, reveals that of the "2.6 billion people who have gained access to improved drinking water since 1990, 1.9 billion gained access to potable water on the spot and that by $2015,91 \%$ of the world's population uses an improved source of drinking water, compared to 76\% in 1990" (UNRIC, 2015, p.7).

All this led in 2015 to the replacement by the UN of the 8 MDGs by the 17 Sustainable Development Objectives that expanded the action plan to achieve full sustainable development on the planet and explicitly bring into the sixth objective drinking water as an important means of promoting human dignity.

It should also be noted that the decade 2018-2028 was declared by the UN the International Decade for Action: Water for Sustainable Development. This reinforces the evolution in the recognition of water as a fundamental human right to life before the international community. 


\section{DEVELOPMENT, SUSTAINABILITY, AND ENVIRONMENT: WATER AS A SUSTAINABLE DEVELOPMENT GOAL}

The understanding of the possibility of an economic development allied to the idea of sustainability has come a long way until it becomes the concept that today bases the future plan outlined by the UN with Agenda 2030 and its objectives of sustainable development.

As presented earlier, the Stockholm Conference is a milestone in the history of valuing the environment in the international arena. However, despite highlighting environmental issues in global discussions, the conference still had at its core concerns of a predominantly economic bias linked to the right to development.

Until that time, the discussions were in the sense of understanding the situation of environmental degradation to enable the essentially economic development. There is only the beginning of a change in this vision after the creation of the World Commission on Environment and Development (WCED) in 1983.

The work of this committee, chaired by Gro Harlem Brundtland, former Minister of Norway, was presented in 1987 and became known as the Brundtland Report" or "Our Common Future". The report broadened the concept of development to encompass the idea of sustainability, conceptualizing sustainable development as meeting the needs of the present without compromising the ability of future generations to meet their own needs.

In this way, understanding development only in view of economic character no longer holds, since "the development process must realize the dignity of the human person by promoting the improvement of the quality of life and the well-being of the population in a rhythm continuous and automatic." (RESENDE, 2015, p. 37).

One of the precursors of this thought, the economist Amartya Sen (2010), winner of the 1998 Nobel Prize in Economics and creator of the Human Development Index (HDI), together with Mahbub UI Haq, conveys the idea of development related to the idea of improving people's lives and the freedoms they enjoy.

Amartya Sen (2010, p.8) lectures on the focus of development on human achievement and on freedom by claiming to be "an adaptation of an old tradition that can be used effectively in formulating a conceptual basis for the analysis of developmental tasks in the contemporary world".

In the same way, Mahbub UI Haq $(1998$, p. 8) understanding that the focus of development should be on people, since "[...] increase human choices, not just income.". According to the author, this new paradigm of human development aims to "[...] the building of human capacities through 
investment in people and the full utilization of these capacities (through the establishment of a context conducive to growth and employment)."

From this, we began to understand the results of the quantifiable indices of quality of life until the in force, such as GDP, with some doubt, since high GDP indices did not represent much when we observed other issues such as "per capita income, probity in public and private relations, educational quality, respect for biodiversity and regulatory reliability of the business environment" (FREITAS, 2016, p.45).

Only by considering this evolution of the idea of development beyond economic development can one understand the importance of publicizing the Brundtland Report in the discussion of sustainability as part of the progress of the countries. It was after the release of this report that UN member states organized the United Nations Conference on Environment and Development, Eco 92, whose landmark was the valorization of the right to development in harmony with the protection of the environment (RESENDE, 2015).

In addition, as a result of ECO-92, guidelines were established for economic, social and environmental progress, as well as several principles of Environmental Law, expressly mentioning the term sustainable development. In 2002, with the Johannesburg Declaration on Sustainable Development, ECO-92 guidelines were reaffirmed as "protection and management of the natural resource base for economic and social development continued as a common goal" (LEITE; CAETANO, 2010, p. 252).

Thus, the protection of the environment has assumed an important role in the right to development, consubstantiating it with sustainable bias, in view of the need to reconcile economic progress with the environment. All this from the understanding that man's activities in relation to production and consumption must respect nature's capacity for resilience, guaranteeing the continuity of natural resources and preventing future generations from being denied the right to satisfy their own needs (RESENDE, 2015).

As a result of this new vision that combines economic progress and environmental responsibility, the UN presented, in 2015, the document "Transforming Our World: The Agenda 2030 for Sustainable Development, "whose 17 sustainable development goals (SDG) and 169 targets show an ambitious plan for the future.

The ambition is in the attempt to achieve full sustainable development and the eradication of poverty in all its forms for the realization of human rights from the fulfillment of the objectives listed in 
the document. Among these objectives, specifically in the sixth one, the availability of drinking water to all as a focus of the sustainable development of the planet.

Regarding the term sustainable development, it is worth presenting the positioning of Juarez Freitas (2016, p. 57) in defending the best use of the term sustainability in substitution to that one, since for the author "sustainability is that it must adjectivate, condition and infuse its characteristics to the development, never the contrary".

In line with this vision, Leite and Caetano (2010) that the exacerbated use of the term sustainable development in the 1990s, in international colloquiums, without further studies and scientific research, the ambiguity and susceptibility of the term that refers to the idea of sustainable development always behind the right to development, having this prominent role, when environment and development should be partners.

In relation to this discussion, one can infer from reading the UN document on SDG, Agenda 2030, valuing sustainability in line with the intended development of the planet. This is clear from one of the principles of the document which recognizes the intrinsic linkage and interdependence of eradicating poverty, combating inequalities, preserving the planet, creating sustained, inclusive and sustainable economic growth and promoting social inclusion (BRASIL, 2015).

In this document, therefore, it is possible to identify the presence of the multidimensional character of sustainability, which is feasible from the social dimension that does not admit a model of development based on exclusion, the ethical dimension based on cooperation in favor of continuity of life, the environmental dimension with a focus on the right to a clean environment for future generations, the economic dimension that supports economics in measuring long-term consequences and the legal-political dimension that determines the legal protection of the right to the future (FREITAS, 2016).

Thus, the sustainability of Agenda 2030, taking into account the environmental dimension of the SDG, is based on the idea of human development by maintaining the environmental balance essential to a life worthy for all.

Considering the new understanding of environmental protection as a mechanism for the development of a State and guaranteeing the quality of life of the population, water, as a natural resource to be protected, is part of this range of environmental protection and is one of the objectives to be achieved as a goal for sustainable development.

This was achieved in the face of the State's compliance with the situation of shortages in the 
supply of drinking water in the world and of the consideration of the finitude of water resources. From then on, it was understood that there is a need to manage these resources in order to guarantee the availability of water in quantity and quality for the present and future generations.

This was one of the points made at the 1992 United Nations Conference on Environment and Development, according to its final document, there is the recognition that freshwater resources are an essential component of the Earth's hydrosphere, which is indispensable for the life and maintenance of all terrestrial ecosystems, and their widespread scarcity, its gradual destruction and the worsening of its pollution urgent planning and integrated management objectives (ONU, 1995).

Following the guidelines drawn up in 1992, the perception of the need for water resources management is also present in Agenda 2030, which includes an extension of this thinking to cover crossborder cooperation in this regard.

As mentioned earlier, Agenda 2030 is an ambitious document and as far as water is concerned there is a challenge for the Member States to meet this objective by 2030. They aim to achieve universal and equitable access to safe drinking water, improve water quality, reduce pollution, increase the efficiency of water use in all sectors, and secure and sustainable withdrawals and fresh water supply to address water scarcity and reduce the number of people suffering from this problem (BRASIL, 2015).

Contrary to the wishes of the States, the UN released the United Nations World Report on Water Resources Development in the first half of 2018, which shows worrisome data regarding the consumption of water on the planet.

Regardless of efforts to implement water resources management measures, the report points to the increasing global demand for water of around $1 \%$ a year and to the rapidly increasing demand for water in homes and industries in relation to the growth of demand in agriculture, but the agricultural sector will continue to be the largest consumer (UNESCO, 2018).

Thus, it is observed that the economy is still a decisive factor in the sustainability model that is intended for the planet, considering that the impact of the economic sectors in the water management reveals itself from this report as an obstacle to the fulfillment of the promises of the Agenda 2030 by the countries.

Likewise, the water crisis that is taking place on the planet jeopardizes the promotion of a decent life for men, since the shortage of water in the different regions makes it impossible to enjoy conditions of quality of life and prevent the complete sustainable human development. 


\section{RIGHT TO A HEALTHY ENVIRONMENT AND THE RIGHT TO WATER: HUMAN RIGHTS}

The scarcity of potable water in the world and the crisis in the management of water resources, as well as the lack of awareness of the population about the proper use of this natural resource, demanded the need to glimpse a new right, fundamental to the maintenance of human life: the right to water.

The new rights arise from the social changes that occur over the years in the history of humanity. Thus, the emergence of the human rights that until today is under construction, because its demand is extended as the social and cultural events develop.

Thus, for example, the emergence of international human rights law, postwar law, is understood by the way it was conceived in the face of the realities brought about by the Second World War, immersed in a context of loss of rights, social devastation of countries and financial recession.

According to Resende (2015), human rights emerged at the end of World War II to protect human dignity, threatened by the warlike episodes facing humanity.

The evolution of this right towards the States can be seen from its strengthening resulting from the decision-making of the United Nations (UN) in mid-1945, marked by the understanding of the promotion of human rights and fundamental freedoms as purposes of its action (PIOVESAN, 2017).

For its part, in 1948, the Universal Declaration of Human Rights inaugurated the contemporary conception of these rights marked by universality and indivisibility. This statement also has as a milestone the conjugation of the value of freedom to the value of equality by merging the liberal discourse (of civil and political rights) and the social discourse of citizenship (of social, economic and cultural rights). From that point on, human rights came to be understood as an interdependent, interrelated and indivisible unity (PIOVESAN, 2017).

The Declaration expressly recognizes the universality of human rights and further states that dignity is inherent in all members of the human family, all persons being free and equal in dignity and rights from birth (RESENDE, 2015).

This change of paradigm in relation to human rights as an object of global protection, corroborated by the emergence of a specific international right to safeguard them, also brought about changes of internal paradigms in the States belonging to its global, regional and local systems, since it promoted the active position of these States in the promotion of human rights internally, in order to achieve an international standard of protection.

It is from this idea of unicity, indivisibility of human rights at the global level, with the work of 
its agents at international, regional and national level, being they States, companies, NGOs and individuals, which is based on the concept of environmental citizenship brought by Canotilho (2010) in view of the idea of the existence of several juridical-analytical postulates when analyzing the juridical problems of the environment, among them, the globalist postulate.

The author explains that, in the light of the globalist postulate, the environmental protection system must be carried out in such a way as to achieve an ecological environmental standard, based on international and supranational legal-political systems and not on the level of isolated legal systems, whether they are state-owned or not (CANOTILHO, 2010).

This thinking does not diminish the importance of state structures and local institutions in protecting the environment, but goes further by indicating an environmental citizenship right in intergenerational terms, since natural heritage, as the author maintains, was not the work of a generation and the right to the environment to which each must be guaranteed, it is also a duty of citizenship in the defense of the environment.

Thus, environmental law proposes a commitment to the future temporal dimension, as affirms Délton Winter de Carvalho (2010), considering the formation of bundles of rights and obligations between members of the current generation as well as of past, present and future generations, under the focus of intergenerational equity that gained prominence in the discussions on the environment since the United Nations Conference in 1972.

This bundle of rights and obligations arising from new rights, environmental law, has as its content the protection of life. It is understood that the decision-making in the present time regarding the way of relating to the environment should aim at the protection of life as a whole and not only the protection of individual life (AYALA, 2002).

It is thus observed that the paradigm change in the way the states communicated and related after the post-war period contributed to an ecological change, making possible the protection of the most effective environment of global action, in the same way that international human rights law made possible the strengthening of democracies and propitiates to date the evolution of these states, marked so recently by dictatorial periods that have tarnished its development.

Given the importance of the discussions on the international scene about the environment and its influence on the internal organization of countries, José Afonso da Silva (2010, p. 69-70) says that the Stockholm Declaration, for example, was the precursor in the ecologically balanced environment recognition movement as a fundamental right in the Constitutions that succeeded it. 
It should also be noted that, in relation to the environment, international human rights law has contributed to the global visibility of Non-Governmental Organizations (NGOs) that have begun to have a recognition of legal position giving relevance to environmental causes before the global summits (PIOVESAN, 2017).

It is also worth mentioning Edis Milaré's understanding that the right to a healthy environment is an extension of the right to life, having two aspects, both that focuses on the physical existence and health of human beings, as well as on the dignity of this existence, what is called "quality of life", being the meaning of what is worth living (RESENDE, 2015, p. 85).

In view of this, the human right to a healthy environment is now a third dimension right among fundamental rights, included in the rights of fraternity, considering the characteristic of not belonging to the individual man, but possess collective, transindividual (RESENDE, 2015).

According to Clara Machado (2017), these third-dimensional rights result from the process of globalization and its positivation is still in progress, considering the transformations that occur continuously in society.

It is in this context that the right to water is inserted, whose need for recognition is due to the changes in society in regard to drinking water supply, where the scarcity of quality and quantity water generated the inevitability of being positive in the international law scenario, indispensable for the dignified human life.

Thus, there is an increase in the role of human rights, in the face of the emergence of the right to water, which is integrated with third-dimensional rights and part of the right to the environment ecologically balanced.

There is a part of the doctrine that understands the existence of the sixth dimension of relative fundamental rights in which the right to water should be highlighted. According to Fachin and Silva (2011), water should be highlighted and built on a plan that justifies the birth of a new dimension of fundamental rights. According to the authors, the scarcity of drinking water, its poor distribution, its unregulated use and pollution in its various forms have the force to share new fundamental rights.

Regarding the international scope, the recognition of water as a human right can be identified in the UN Development Program Human Development Report published by the UN in 2006, as well as UN: A/RES/64/292 (UN, 2018), of July 28, 2010; A/HRC/RES/15/9 (UN, 2018), October 6, 2010; and A/RES/70/169 (UN, 2018), of February 22, 2016.

It is important to mention that some Latin American constitutions expressly provide for the 
human right to potable water, such as the Constitution of Bolivia, which in its article 20, item III, says: “El acceso al agua y alcantarillado constituyen derechos humanos, no son objeto de concesión ni privatización y están sujetos a régimen de licencias y registros, conforme a ley." (BOLIVIA, 2009); a Constituição do Equador que versa em seu artigo 12: "El derecho humano al agua es fundamental e irrenunciable. El agua constituye patrimonio nacional estratégico de uso público, inalienable, imprescriptible, inembargable y esencial para la vida." (ECUADOR, 2008); and the Constitution of Uruguay which expressly states in Article 47:

La protección del medio ambiente es de interés general. Las personas deberán abstenerse de cualquier acto que cause depredación, destrucción o contaminación graves al medio ambiente. La ley reglamentará esta disposición y podrá prever sanciones para los transgresores. El agua es un recurso natural esencial para la vida. El acceso al agua potable y el acceso al saneamiento, constituyen derechos humanos fundamentales. (URUGUAY, 1967).

This is due to the advance of the new Latin American constitutionalism that brings a new perspective on natural goods, "before the new legal and social framework, the until then unknown rights of nature (Pachamama) and the constitutionalization of a proposal [...] of buen vivir [...]" (MACHADO, 2017, p. 115).

The new Latin American constitutionalism, classified as Andean, pluralist, intercultural and community constitutionalism, notably in the field of the environment, has promoted a substantial transformation in the juridical parameters hitherto adopted in the Western world, offering elements for what the scholars of the subject are calling of ecocentric gyration and republican bissocialism [...] (MACHADO, 2017, p. 115).

The countries that present this new constitutionalism take a leap forward in the view on the previously anthropocentric relationship between man and nature to recognize the uniqueness of life forms. At this point, it is convenient to present the understanding of Augusto César Leite de Resende that says "The interdependence and interconnection between man and nature are blatant because there is no possibility of separating man from the natural environment by the simple fact that it is nature who provides life to humans" (RESENDE, 2016, p. 47).

In Brazil, there is still no recognition of the rights of nature as the countries previously mentioned already do, nor is there specific constitutional provision on water as a fundamental right, but this natural resource receives constitutional treatment as a good of the Union and States, in Title III, of the State Organization, Chapter II (BRASIL, 1988).

However, it is observed that the country has been advancing in the theme of the recognition 
of water as a human right, and the understanding that "access to drinking water is an indispensable element for the realization of life with dignity because man does not live isolated from nature" has gradually strengthened (RESENDE, 2017, p. 273).

An example of this can be seen in the initiative of the Brazilian Federal Public Ministry, which, during the 8th World Water Forum, held on March 21, 2018, in Brasilia, together with representatives of eight other countries, presented the Right to Water (verbal information) ${ }^{4}$.

The Declaration ${ }^{5}$ recognizes the human right to water and states as the first principle:

The human right to water and sanitation must be recognized and applied in its maximum effectiveness by all public and private spheres of power, and it is a necessary condition for the promotion of another individual, social and cultural human rights, and logical presupposition respect for the dignity of the people (MINISTÉRIO PÚBLICO FEDERAL, 2018).

After all, "drinking water is absolutely necessary for the realization of the essential minimum for a dignified life, that is to say, of the existential minimum, since without it, not even physical survival is guaranteed, as far as life with dignity is concerned." (RESENDE, 2017, p. 275).

Another Brazilian initiative that highlights the importance of water in the respect of human dignity, as well as of other forms of life, is evidenced in the Projeto Conexão Água ${ }^{6}$, also on the initiative

\footnotetext{
${ }^{4}$ This information was provided during a speech of Dr. Ivana Farina, at the 23rd Congress of Environmental Law, held in São Paulo, from May 26 to 302018.

${ }^{5}$ The declaration lists ten principles: the defense of water as a human right; water and the ecological function of properties; the right to water for indigenous people and traditional populations; water as an element of social inclusion; water governance; water from the perspective of prevention and precaution; the principle in dubio for Water; the importance of the polluter-payer and user-payer relationship; water and environmental integration; and the relationship between water and justice access.

${ }^{6}$ The presentation of the work of the Water Connection Project was carried out by Dr. Sandra Kishi, during the programming of the 23rd Law Congress Environmental, occurred in São Paulo, from May 26 to 30, 2018. About the project access: http://conexaoagua.mpf.mp.br/.
}

\section{BIBLIOGRAPHIC REFERENCES}

AYALA, Patryck de Araújo. Direito e incerteza: a proteção jurídica das futuras gerações no Estado de direito ambiental. 2002. 372 f. Dissertação (Mestrado) - Curso de pós-graduação em Direito, Centro de Ciências Jurídicas, Universidade Federal de Santa Catarina, Florianópolis, 2002.

BOLIVIA. Constitución Política del Estado (CPE). 2009. Disponível em: 
<https://www.oas.org/dil/esp/Constitucion_Bolivia.pdf>. Acesso em: 10 jun. 2018.

BRASIL. Constituição (1988). Constituição da República Federativa do Brasil. Diário Oficial da República Federativa do Brasil, Brasília, DF, 5 out. 1988. Disponível em: <http://www.planalto.gov.br/ccivil 03/constituicao/constituicao.htm>. Acesso em: 10 jun. 2018.

BRASIL. Itamaraty. Transformando Nosso Mundo: A Agenda 2030 para o Desenvolvimento Sustentável. 2015. Disponível em: <http://www.itamaraty.gov.br/images/ed desenvsust/Agenda2030-completosite.pdf>. Acesso em: 03 jun. 2018.

BRASIL. Ministério do Meio Ambiente. Declaração da Conferência de ONU no Ambiente Humano. Brasília, DF, 1972. Disponível em: < www.mma.gov.br/estruturas/agenda21/ arquivos/estocolmo.doc >. Acesso em: 02 jun. 2018.

CANOTILHO, José Joaquim Gomes. Estado Constitucional Ecológico e Democracia Sustentada. In: LEITE, J.; FERREIRA, H.; BORATTI, L. (Orgs.). Estado de direito ambiental: tendências. 2. Ed. Rio de Janeiro: Forense Universitaria, 2010. p. 31-44.

CARVALHO, Délton Winter de. A tutela constitucional do risco ambiental. In: LEITE, José Rubens Morato.; FERREIRA, Heline Sivini; BORATTI, Larissa Verri (Orgs.). Estado de direito ambiental: tendências. 2. Ed. Rio de Janeiro: Forense Universitaria, 2010. p. 261-282.

CONEXÃO ÁGUA. Conexão Água - Atuação Colaborativa Estratégica e Transparente para a Preservação das Águas e Qualidade de Vida. Disponível em: <http://conexaoagua.mpf.mp.br/>. Acesso em: 05 jun. 2018.

ECUADOR. Constitución de la República del Ecuador 2008. Disponível em: <http://www.oas.org/juridico/pdfs/mesicic4_ecu_const.PDF> .Acesso em: 10 jun. 2018.

FACHIN, Zulmar; SILVA, Deise Marcelino. Direito humano e fundamental de acesso à água potável - a caminho da constitucionalização. In: BERTOLDI, Márcia Rodrigues; SPOSATO, Karyna Batista (Orgs.). Direitos humanos: entre a utopia e a contemporaneidade. Belo Horizonte: Fórum, 2011. p. 249-262.

FREITAS, Juarez. Sustentabilidade direito ao futuro. 3. ed. Belo Horizonte: Fórum, 2016.

HAQ, Mahbub UI. Capítulo 2 - O paradigma do Desenvolvimento Humano. In: HAQ, Mahbub UI. Introdução ao Desenvolvimento Humano: Conceitos Básicos e Mensuração. PUC Minas Virtual. Disponível em: <https://docslide.com.br/documents/o-paradigma-do-desenvolvimento-humanomahbub-ul-haq.html> . Acesso em: 30 maio 2018.

INTERNATIONAL ENVIRONMENTAL LAW RESEARCH CENTER. United Nations Water Conference, 1977 (Resolutions). Geneva: International Environmental House. Disponível em: <http://www.ielrc.org/content/e7701.pdf> . Acesso em: 02 jun. 2018.

LEITE, José Rubens Morato; CAETANO, Matheus Almeida. As facetas do significado de desenvolvimento sustentável: uma análise através do estado de direito ambiental. In: PIOVESAN, Flávia; SOARES, Inês Virgínia Prado. (Orgs.). Direito ao desenvolvimento. Belo Horizonte: Fórum, 2010. p. 249-274. 
LIBERATO, Ana Paula. Direito humano fundamental ao meio ambiente ecologicamente equilibrado. In: FOLMANN, M.; ANNONI, D. (Orgs.). Direitos humanos: os 60 anos da declaração universal da ONU. Curitiba: Juruá, 2010. p. 19-29.

MACHADO, Carlos Augusto Alcântara. Considerações sobre a tutela do meio ambiente na Constituição do Brasil de 1988 e no constitucionalismo Latino-Americano. In: Ambiente e diritti tra responsabilità e partecipazione. Canterano: Aracne editrice, 2017. p. 105-121.

MACHADO, Clara. O Princípio Jurídico da Fraternidade: Um instrumento para proteção de direitos fundamentais transindividuais. Rio de Janeiro: Lumen Juris, 2017.

MINISTÉRIO PÚBLICO FEDERAL. Declaração do Ministério Público sobre o Direito à Água. Disponível em: <http://www.mpf.mp.br/pgr/documentos/Declaracao do Ministerio Publico.pdf>. Acesso em: 05 jun. 2018.

ORGANIZAÇÃO DAS NAÇÕES UNIDAS. A história da organização. Disponível em: <https://nacoesunidas.org/conheca/historia/> Acesso em: 02 jun. 2018.

ORGANIZAÇÃO DAS NAÇÕES UNIDAS. Conferência das Nações Unidas sobre o Meio Ambiente e Desenvolvimento. Rio de Janeiro, $1995 . \quad$ Disponível em: <http://www.onu.org.br/rio20/img/2012/01/agenda21.pdf> . Acesso em: 02 jun. 2018.

PIOVESAN, Flávia. Direitos humanos e o direito constitucional internacional. 12. ed. São Paulo: Saraiva, 2011.

PIOVESAN, Flávia. Temas de Direitos Humanos. 10. ed. São Paulo: Saraiva, 2017.

RESENDE, Augusto César Leite de. A tutela jurisdicional do direito humano ao meio ambiente sadio perante a corte interamericana de direitos humanos. 1. ed. Belo Horizonte: Fórum, 2015.

RESENDE, Augusto César Leite de. O acesso à água potável como parcela do mínimo existencial: reflexões sobre a interrupção do serviço público de abastecimento de água por inadimplemento do usuário. Revista Brasileira de Políticas Públicas (Online), Brasília, v. 7, n. 2, p. 265-283, ago. 2017.

RESENDE, Augusto César Leite de. O reconhecimento da dignidade dos elementos da biodiversidade com base no diálogo entre o direito internacional e o ordenamento jurídico brasileiro. Revista de Direito Internacional, Brasília, v. 13, n. 2, p. 38-51, 2016.

SEN, Amartya. Desenvolvimento como liberdade. Trad. Laura Teixeira Motta. São Paulo: Companhia das Letras, 2010.

SEN, Amartya. O desenvolvimento como expansão de capacidades. Lua Nova, São Paulo, n. 2829, p.313-334, abr. 1993.Disponível em <http://www.scielo.br/scielo.php?script=sci arttext\&pid=S010264451993000100016\&lng=pt\&nrm=iso > . Acesso em: 02 jun. 2018. 
of the Federal Public Ministry, which is "a collaborative network for the improvement of water quality and quantity in Brazil and Participative and Transparent Water Governance, made up of representatives of the various sectors of civil society and government" (CONEXÃO ÁGUA, 2018).

This project focuses on facilitating access to information on water quality. The purpose of the project is to encourage social control and participatory management of water, providing the people with the role of the actor of effective changes towards public health and environmental harmony, respecting all forms of life (CONEXÃO ÁGUA, 2018).

This project focuses on facilitating access to information on water quality. The purpose of the

SILVA, José Afonso da. Direito Ambiental Constitucional. 8. ed. São Paulo: Malheiros, 2010.

UNESCO. Organização das Nações Unidas para a Educação, a Ciência e a Cultura. Relatório Mundial das Nações Unidas sobre Desenvolvimento dos Recursos Hídricos 2018. Disponível em: <http://unesdoc.unesco.org/images/0026/002615/261594por.pdf> . Acesso em: 05 jun. 2018.

UNITED NATIONS. Resolution adopted by the General Assembly on 17 December 2015. The human rights to safe drinking water and sanitation. Disponivel em: < http://www.un.org/en/ga/search/view_doc.asp?symbol=A/RES/70/169>. Acesso em: 10 jun. 2018.

UNITED NATIONS. Resolution adopted by the General Assembly on 28 July 2010. Disponível em: <https://documents-dds-ny.un.org/doc/UNDOC/GEN/N09/479/35/PDF/N0947935.pdf?OpenElement>. Acesso em: 10 jun. 2018.

UNITED NATIONS. Resolution adopted by the Human Rights Council. Human rights and access to safe drinking water and sanitation. Disponível em: <https://documents-ddsny.un.org/doc/UNDOC/GEN/G10/166/33/PDF/G1016633.pdf?OpenElement>. Acesso em: 10 jun. 2018.

UNITED NATIONS. The Dublin Statement On Water And Sustainable Development. Dublin, 1992. Disponivel em: <http://www.un-documents.net/h2o-dub.htm> . Acesso em: 03 jun. 2018.

UNRIC. Centro Regional de Informação das Nações Unidas. Relatório sobre os objetivos do milênio 2015. Disponível em: <https://www.unric.org/pt/images/stories/2015/PDF/MDG2015 PT.pdf>. Acesso em: 02 jun. 2018.

URUGUAY. Constitución Política de la República Oriental del Uruguay de 1967. Disponível em: <http://pdba.georgetown.edu/Constitutions/Uruguay/uruguay04.html>. Acesso em: 10 jun. 2018.

WORLD HEALTH ORGANIZATION. International Drinking Water Supply and Sanitation Decade, 1981. Disponível em: <http://www.who.int/neglected_diseases/mediacentre/WHA 34.25 Eng.pdf>. Acesso em: 03 jun. 2018. 
project is to encourage social control and participatory management of water, providing the people with the role of the actor of effective changes towards public health and environmental harmony, respecting all forms of life.

\section{FINAL CONSIDERATIONS}

The consideration of the environment, as well as its conception as a human right, essential to the quality of life and the promotion of human dignity, on the international scene, has occurred in a sensitive and progressive way from the 70's to the present day.

In this evolution of the understanding of the environment by the states, the UN action that since its creation in 1983 promoted world conferences that highlighted the environmental theme and provided the construction of the model of the human right to the healthy environment that exists today internationally.

Allied to the human right to the ecologically balanced environment, it is evident the increasing progress of the valorization of water as a human right also is fundamental to human dignity. This conception has been diffused from the observation of the need to elevate to the global discussions on the theme water, in view of the problems of scarcity, mismanagement and water crisis that appear around the world.

This change of paradigm in relation to water has occurred in a gradual way, considering the several conferences organized by the UN in the past decades and reinforced increasingly in the present time.

Specific global water meetings, as well as the designations of international water decades from 1981 to 1990, from 2005 to 2015, and more recently from 2018 to 2028 were essential to change the design in the way the water as a human right necessary for the dignified life of men.

The very recognition of water as a human right in the body of the United Nations Development Program's Human Development Report published by the UN in 2006 reinforces this new understanding of water as a fundamental right to life.

Although in the Brazilian case, there is still no mention of such human rights, there is the appreciation of water in the list of human rights in Latin American countries, such as Bolivia and Ecuador. This, therefore, evidences the possibility of a future transformation of the way the right to water in the Brazilian scenario is conceived.

Examples of this can already be seen in the work of the Brazilian Federal Public Prosecutor's 
Office, which, through the Water Connection Project, as well as through the initiative of the Public Prosecutor's Declaration on the Right to Water, demonstrate compliance with the evolution of discussions on water in neighboring countries and around the world.

In the face of all that has been exposed, it is noted that the right to water is already recognized at the international level, despite the fact that Brazil is still against this understanding, and that this is due to the increase in environmental and more specifically water-related issues in the context of UN discussions that reinforced and culminated in the perception of the importance of water as a sustainable development objective of Agenda 2030 for the future of the planet.

Trabalho enviado em 18 de março 2019

Aceito em 02 de fevereiro de 2020 